\title{
Failing to Share the Burden: Traditional Donors, Southern Providers, and the Twilight of the GPEDC and the Post-War Aid System
}

\author{
Gerardo Bracho
}

\subsection{INTRODUCTION}

In November 2011, at a High-Level Meeting in Busan, Korea, all the main state actors of the international development cooperation agenda (traditional Development Assistance Committee [DAC] donors, new non-DAC donors, providers of South-South cooperation, and recipient partner countries) came together with other stakeholders to create a new platform to be run jointly by the Organisation for Economic Co-operation and Development (OECD)-DAC and the United Nations Development Programme (UNDP): the Global Partnership for Effective Development Co-operation (GPEDC). ${ }^{1}$ The GPEDC was expected to be a place where traditional DAC donors (DDs) and emerging South-South cooperation (SSC) providers would work together to discuss and eventually adopt standards, norms, and commitments in order to improve their development cooperation and align it with the interests of

Gerardo Bracho is a Mexican diplomat and Associated fellow at the Centre for Global Cooperation Research. Mr. Bracho is a member of the Mexican Foreign Service, though he takes full responsibility for the views expressed in this paper, which should not be attributed to the Mexican government. He would like to thank Brian Atwood for his valuable comments on this subject as well as André de Mello e Souza, Heiner Janus, and Elizabeth Amann for their valuable corrections and suggestions.

\footnotetext{
G. Bracho $(\bowtie)$

Paris, France
}

(C) The Author(s) 2021 
recipient countries (RCs) and the "common good". In Busan, these two state actors seemed to reach a deal on an ad hoc "burden-sharing" framework based on "differential commitments". The GPEDC was set to incarnate a new global regime of effective development cooperation. ${ }^{2}$

By 2014, however, the Busan agreement laid in tatters as the main Southern providers (China, India, and Brazil) boycotted the first GPEDC High-Level Meeting (HLM) in Mexico City. ${ }^{3}$ Since then, the GPEDC has followed an erratic course without them, and neither the UN Development Cooperation Forum nor any other institution has emerged to replace it. To gauge the fate and the potential of the GPEDC, it is important to understand why the Busan compromise fell short of its promise. Indeed, the episode illustrates the difficulties that new emerging powers (EPs) face when they attempt to join the post-war liberal order on terms that reflect their new status and potential. Are they capable and/or willing to join this order that is now in flux and also threatened from within by rising populism and nationalism? Is this order willing to make a proper space for them? Will at least some of them try to construct an alternative and competing order, as happened during the Cold War? The analysis of the relations between the GPEDC and the Southern providers can throw some light on these and similar questions.

In a recent essay (Bracho 2017), I reconstructed in some detail the history of the relations between Southern providers and the DAC-sponsored aid effectiveness agenda from the Paris Declaration (2005) to the GPEDC HLM meetings in Mexico City (2014) and Nairobi (2016). Building on this analysis, the first section of this essay briefly reconstructs the path to the Busan agreement. The second section presents an abstract "burden-sharing" model to highlight the issues at stake. The third section uses this model to explain why the Busan agreement collapsed. The final section offers conclusions based on this analysis.

\subsection{The Promise and Failure of Busan ${ }^{4}$}

Since its inception in 1960, the DAC has represented itself as a "standardsetting" institution: the place that created the concept of ODA and where the norms and "good practices" of donorship are established and administered. Like other OECD bodies, the DAC has a double task: It establishes standards for its members and, through "outreach", it attempts to recruit new members and encourage actors outside its membership to adopt its standards. In the last couple of decades, as "new donors" have appeared or re-emerged on the scene, the DAC has been relatively successful: It has eight new members and four "participants", while another 16 countries regularly report their ODA to the DAC (Gulrajani and Swiss 2017).

It has been much less successful, however, in convincing the other 10 or so "new donors" from the South-the "Southern providers"-to join the agenda. These include even OECD members, such as Mexico and Chile. These 
actors share two distinctive features. First, they are still recognised by the international system and the DAC itself as "developing countries". ${ }^{5}$ For the most part, they are classified as upper-middle-income countries: Though relatively wealthy, they still face many development challenges and thus have a right to receive ODA $^{6}$ (Besharati 2013; Bracho 2015).

Second, as developing countries, they have been cooperating with peer countries for many decades under the SSC tradition born in Bandung in 1955. They have thus their own narrative about development (though with few codified standards and norms), which, in many ways, is opposed to that of the DAC. As was to be expected, co-opting or even cooperating with these actors as donors has turned out to be challenging.

Until recently, the DAC tried to cooperate with Southern providers, mainly through the effectiveness agenda. This is an "action agenda" in which all participants are expected to commit to specific tasks and policies to make the cooperation they provide or receive more transparent and effective. Its founding document - the Paris Declaration of 2005-embraced precise and quantifiable commitments for two state actors: donors and recipients. Some new donors - for example, the East Europeans-had no problem in accepting this. But the Southern providers, averse to being treated as "donors", refused to play along. After years of deliberating on how they might fit into an agenda devised for traditional donors and recipients, they finally agreed to participate in Busan as "providers of South-South cooperation" (Busan Article 14); that is, as a third bilateral actor seen as a special kind of donor and requiring differential treatment. Indeed, Busan was widely considered a success because it managed to bring the Southern providers on board (Atwood 2012; Eyben and Savage 2013; Kharas 2011; Kim and Lee 2013; Kindornay and Samy 2012; Lightfoot and Kim 2017).

The fact that the main Southern providers (China, India, and Brazil) signed the outcome document in Busan, along with all other countries that fit in this category (e.g. Mexico, Thailand, Turkey, Indonesia, South Africa, Chile), seemed to indicate that the Southern providers had finally found their place in the new Partnership. First, in contrast with Paris, they participated in the drafting of the Busan outcome document, in which they made a place for themselves, especially in Articles 2 and 14. Second, they were fully incorporated in the governing structure of the new GPEDC, represented in one of three ministerial co-chair slots and also in an extra one on the Steering Committee. Third, in joining, they recognised "common goals"the Millennium Development Goals (MDGs)—and "shared principles", but on the understanding that SSC was different and that they would have "voluntary" and "differential commitments"; the latter concept being a proxy for common but differentiated responsibilities (CBDR), which Mexico originally introduced in the outcome draft, supported by the following argument: 
The concept (CBDR) is not meant to allow DAC donors to repudiate or dilute their responsibilities. It is neither meant to allow new large South-South providers to "do nothing". On the contrary, it is meant as a way to incorporate us, the latter ones, into the agenda, at a realistic and appropriate level given our middle-income countries' condition. (Working Party on Aid Effectiveness [WP-EFF] 2011)

The donors, however, were not happy with CBDR, which in climate change negotiations had been interpreted negatively as the absence of responsibilities. In this context, "differential commitments" emerged as a compromise concept, which, according to the Mexican rationale, implied that Southern providers were indeed willing to commit, though at a differentiated level. The idea was to put forward a positive interpretation of CBDR more closely linked to its literal meaning. The promise of Busan depended on this nuance.

The weak link, however, was the monitoring framework of the GPEDC, which evaluated compliance with 10 specific commitments: five for "providers", three for recipients, and two presumably for both. The "provider commitments" had been conceived by and for traditional donors. As Southern providers had not committed to them and considered them inappropriate to their unique situation, they were opposed to being evaluated by these criteria.

In an ideal world, Southern providers would have defined which, if any, of those commitments they could take on board and at what "differential" level; if unable to accept some, they would have been encouraged to propose alternative definitions and measures that better reflected their own circumstances. But the real world was very different. First, it was not clear which countries should belong to this new constituency of "Southern providers". Although there was a long-standing narrative about SSC, it had been developed at a very different time and encompassed all developing countries engaging in horizontal technical cooperation among equals - a narrative enshrined in the Buenos Aires Plan of Action (1978). Southern providers, however, were generally considered to be a smaller subgroup of EPs-generally richer and/or more capable of providing support to poorer/weaker developing countries and using a broader set of cooperation instruments. But which countries belonged to this subgroup exactly? This was not clear.

There was also little consensus about what counted as the cooperation they supplied. There was a shared perception that ODA was a "Northern flow", but there was no consensus as to how to define SSC. Would it involve only flows or also pro-development policies? And if the former, how would they be monetised given that much SSC was given in kind rather than in cash? The monitoring framework required indicators of performance, and these, in turn, required a clear definition of SSC in monetary terms. In sum, to participate properly in the Busan monitoring framework, Southern providers needed a new tailor-made narrative to underpin their new "differential commitments". This narrative did not exist, and it was not clear who and which institution 
should create it (Besharati 2013; Bracho 2015; Fues 2016, 2018; Quadir 2013).

To bridge the gap between the ideal and the real world, the Korean hosts (supported by Mexico, Brazil, and the DAC chair) came up with a deal on the "participation of South-South cooperation providers in the Busan Global Monitoring framework". Taking as a starting point "the different nature of South-South cooperation", the agreement stated:

These new providers of assistance are not expected to participate in the global system proposed in this initial Partnership arrangement. Their future participation in aspects of the global system is a decision left to evolving and sovereign processes, and this will in no way inhibit their full participation in the Partnership as South-South partners. (WP-EFF 2012) ${ }^{7}$

The "Korean deal" was adopted by the GPEDC, but in order for it to endure two things had to take place. First, on the basis of their own "sovereign processes", the Southern providers had to develop their own narrative and their own "differential commitments". Second, while this was being sorted out, the GPEDC had to keep its word and leave the Southern providers temporarily out of the monitoring process.

Unfortunately, none of this happened. After Busan, a number of more or less legitimate Southern initiatives in search of a new narrative were initiated, but they produced few results. ${ }^{8}$ At the same time, the Southern providers failed to work together in the GPEDC and made no effort to link those other discussions, however inconclusive, with the Partnership. On the eve of the GPEDC meeting in Mexico, their agenda had not advanced an inch.

Around the same time, the results of the first monitoring exercise of the GPEDC were made public. Though based on legitimate data provided by RCs, the report broke with the spirit of the Korean deal: The provider activities of China and India were monitored and subject to practically the same scrutiny as those of the traditional donors. Surprisingly, neither the traditional donors nor the Southern providers seemed to care or even notice. By then, both had withdrawn their support for the "differential commitments" formula that had underpinned the Busan promise and the Korean deal.

The collapse of this deal hollowed out the framework through which Southern providers were expected to participate in the GPEDC. As a result, the negotiations over the communiqué for the Mexico HLM started again from square one, as if Busan had never happened. Indeed, much of the substance of the negotiations between traditional donors and Southern providers-this time through a Mexican facilitator-was once again about "who should do what". Southern providers (China especially) complained that traditional donors intended to exaggerate the role of SSC; vice versa, traditional donors accused Southern providers of assuming no commitments and overemphasising the role of North-South cooperation. But now, with "differentiation" off the table, the middle ground had disappeared, 
and the negotiations went nowhere. In the end, dissatisfied with their whole GPEDC experience, the main Southern providers-China, India, and (partially) Brazil-decided not to participate in the first meeting of the Partnership in Mexico City (2014). They have not returned since. The Busan compromise collapsed and the GPEDC lost its global and inclusive character (Bracho 2017).

\subsection{A Simple Burden-Sharing Model of the Bilateral Negotiations at the GPEDC}

There are a number of papers on why and how the Southern providers left the GPEDC-Or as some (wrongly) would have it, never really joined in the first place (Constantine et al. 2015; Li 2017; Li et al. 2018). Though these papers are weak in their historical narrative, most of the explanations that they have put forward are in one way or another relevant. There is one underlying factor, however, that has been overlooked in the literature and operated at a deeper level throughout the political negotiations in both Busan and Mexico City. As I suggest in my narrative above, this is the failure of traditional donors and Southern providers to compromise on the crucial issue of their identities and the responsibilities attached to them. In other words, the Busan compromise collapsed mainly on the question of who does what or, in other words, of burden-sharing.

To better analyse the issue, I present below an abstract model of a "burden sharing game". Before doing so, however, we need to understand how does burden-sharing play out in the development agenda. The starting point to answer this question, is to recognise that aid represents an effort, and thus a burden for donors. If supplying development aid is rarely a purely altruistic endeavour, this does not mean that there is no effort, and thus burden, involved. This burden is quite straightforward when we refer to quantity: As any other official flow, aid implies a budgetary effort. Matters are more complicated when we move to quality, since here the costs or burdens implied are sui generis - as is the case of the costs of complying with the aid effectiveness agenda.

First, there are administrative costs that arise from keeping with the effectiveness commitments. ${ }^{9}$ But there are also costs at a deeper and more important level, because donor countries must "sacrifice" a degree of sovereignty, as when they join any international regime. In principle, donors could subordinate all the aid they give to their own political and/or economic interests and present it to the RCs as a "take it on these terms or leave it" proposition-though, of course, a degree of "mutual benefit" should be involved for aid to materialise at all. ${ }^{10}$ In such case, they have an incentive to give more (though worse) aid, in their own (egoistic) terms, often in a "race-to the bottom" competition with others-as was the case in the Cold War, and as I will argue is, to a certain extent, becoming the case again. The point of the GPEDC, with its commitments and monitoring framework, is to encourage donors to refrain at least in part from such behaviour and to adopt practices 
that directly further the common good, even at the expense of relegating their immediate national interests. To the extent that the benefits from aid accrue to all players, irrespective of their contribution (i.e. in reducing pollution, poverty, uncontrolled mass migration, terrorism, etc.), a system that encourages good aid can be perceived as a global public good (Kaul 2000). In this case, the usual mismatch between individual costs and global rewards brings up the issue of collective action and the problem of free riding (North 2005 [1990]; Olson 1965). When new players appear in an area in which established players are well organised and produce a public good through an implicit or explicit burden-sharing agreement, the latter will naturally try to encourage the former to follow the same rules in order to avoid unfair competition and free riding. This reasoning was, in fact, a crucial underlying driver that moved DAC donors to bring the Southern emerging powers into the GPEDC.

In the aid effectiveness context, moreover, burden-sharing is not straightforward because the burden to share is not fixed, as it is in the case of the costs to maintain a multilateral organisation (which is mostly a zero-sum game). As development has revealed itself to be a more complex and less tangible objective than the founding fathers of the development paradigm originally thought, the aid burden that must be divided among the various donors is not particularly fixed: All donors are expected to comply with the effectiveness standards and with the 0.7 per cent gross national income target, irrespective of what others do.

Now that some of the specificities of burden-sharing in the aid agenda have been explored, we are ready to move on. To the extent that development aid, both in its quantity and quality (effectiveness), represents an effort-and thus a burden - for donors, negotiations among donors and between donors and recipients often involve bargaining over burden-sharing. To better capture the logic of these negotiations in the aid effectiveness agenda, Table 17.1 presents an abstract burden-sharing game with four possible scenarios and three players: DAC donors, Emerging Powers, and Recipient Countries. ${ }^{11}$ In each scenario, DDs and EPs incur costs, considered as foregone national benefits due to their compliance with the aid effectiveness agenda. These costs are (arbitrarily) set to five units for full responsibilities or commitments and only two for lessstringent, differentiated ones. Each level of costs is linked to a distinctive identity in the international cooperation architecture. These costs measure the effort of suppliers, but also the benefit of recipients and the common good: the greater the effort, the larger the benefits. In this respect, the model optimistically assumes: First, that by complying with the effectiveness agenda, providers generate matching benefits on the receiving end. Second, that the benefits directed to the RCs, usually to their standing governments, serve the common good. These assumptions, of course, often do not reflect reality.

The four scenarios with their corresponding outcomes are summarised in Table 17.1.

Scenario A represents the status quo of a North-South divide paradigm with just two players, in which Southern powers go unnoticed under the 
Table 17.1 The burden-sharing game

\begin{tabular}{|c|c|c|c|c|c|c|c|}
\hline \multicolumn{2}{|c|}{ Scenarios } & \multicolumn{2}{|c|}{$\begin{array}{l}D A C \text { donors } \\
(D D s)\end{array}$} & \multicolumn{2}{|c|}{$\begin{array}{l}\text { Southern emerging } \\
\text { powers (EPs) }\end{array}$} & \multirow{2}{*}{ 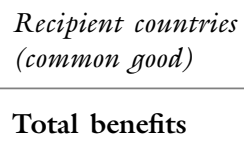 } & \multirow{2}{*}{$\begin{array}{l}\text { North-South } \\
\text { divide }\end{array}$} \\
\hline & & Identity & Costs & Identity & Costs & & \\
\hline A) & $\begin{array}{l}\text { Status quo } \\
\text { with only } \\
\text { responsibilities } \\
\text { for DDs }\end{array}$ & Donor & 5 & $\begin{array}{l}\text { SSC } \\
\text { partner }\end{array}$ & 0 & 5 & \\
\hline B) & $\begin{array}{l}\text { Equal } \\
\text { responsibilities } \\
\text { for DDs and } \\
\text { EPs }\end{array}$ & Donor & 5 & Donor & 5 & 10 & Unchanged \\
\hline C) & $\begin{array}{l}\text { Differentiated } \\
\text { responsibilities } \\
\text { for EPs (with } \\
\text { no change for } \\
\text { DDs) }\end{array}$ & Donor & 5 & $\begin{array}{l}\text { SSC } \\
\text { provider }\end{array}$ & 2 & 7 & $\begin{array}{l}\text { Nuanced } \\
\text { (adapted to } \\
\text { new realities) }\end{array}$ \\
\hline D) & $\begin{array}{l}\text { Towards no } \\
\text { responsibilities }\end{array}$ & Provider & $\rightarrow 0$ & $\begin{array}{l}\text { SSC } \\
\text { partner }\end{array}$ & 0 & $\rightarrow 0$ & Dissolved \\
\hline
\end{tabular}

Source Author

common identity of "developing countries" with a right to ODA and a tradition of providing (modest) SSC flows. In this scenario, the DAC donors bear all the responsibilities. Total costs/benefits amount to 5 . Scenario B represents a situation in which Southern powers appear as donors tout court and have the same responsibilities as traditional donors. Total costs/benefits amount to 10. In scenario C, Southern powers appear with a new identity as Southern providers; they are now considered a special type of donor with a right to ODA but with lower and/or fewer tailor-made differentiated responsibilities as providers. ${ }^{12}$ Meanwhile, the traditional donors retain their usual burdens. Total costs/benefits amount to 7. Finally, in scenario D, Southern EPs retain their traditional identity of developing countries with no responsibilities (as in scenario A), but now the traditional donors reinvent themselves as "providers" and begin to shed their historical responsibilities. Total costs/benefits tend towards 0 .

The game starts with scenario A. Then a new set of players-the emerging Southern powers-arrive on the scene, disrupting the status quo and unleashing a burden-sharing game. The DAC donors will naturally try to co-opt these new players into their own regime. They will thus strive towards scenario $\mathbf{B}$, in which all providers assume full responsibilities - the situation that generates the greatest benefits for RCs (10 units). But the Southern powers will consider this burden-sharing arrangement unfair, and thus unacceptable, since it does not recognise their situation as developing countries with their own development challenges. They would rather preserve the status quo of scenario A. But traditional donors now consider this old scenario-in 
which they bear all the responsibilities- to be outdated and also unfair. Moreover, scenario A generates fewer benefits for recipients (only 5 units). Two scenarios are now left. The first is scenario $\mathbf{C}$ with its differentiated responsibilities. This scenario is a compromise in which, unlike scenarios $\mathbf{A}$ and $\mathbf{B}$, both traditional and Southern powers - now with the new identity of Southern providers-gain something, though not as much as they might like: Traditional donors incorporate the Southern powers into the effectiveness system, whereas the latter agree to join, but at a differentiated level. This is a burden-sharing agreement that both players can consider just and that generates greater benefits for recipients ( 7 units) than the status quo ( 5 units). Though not the first choice of any of the actors, it clearly represents the best collective outcome for this burden-sharing game. The other option is scenario $\mathrm{D}$, which involves no responsibilities. This scenario of no compromise is the same as scenario A, but here the traditional donors, unhappy with the status quo, assume a new identity and begin to shed their own responsibilities: The quality or effectiveness of aid now begins to decline, moving towards 0 . This is the worst outcome for recipients and for the common good as well.

\subsection{Applying the Burden-Sharing Model to Better Understand the Collapse of the Busan Promise}

I will now return to the historical narrative of Sect. 17.1 to show how this simple model helps to explain the dynamics of the negotiations among state actors in the effectiveness agenda and beyond. The status quo (i.e. scenario A) represents the workings of the post-war aid system that emerged in the 1950s and was based on only two types of state actors: donors with the responsibility to give aid, and recipients with the right to receive it. In this clear-cut, bipolar, North-South divide, the latter were expected to eventually leave underdevelopment behind, "graduate" (i.e. reach development), transform themselves in donors, and eventually join the DAC (or adopt its best practices), agreeing thus to "share the burden" with full donor responsibilities, as depicted in scenario B. As we saw in Sect. 17.1, a number of "emerging donors" have moved from scenario A to scenario B; the DAC has grown from eight members in 1960 to 30 members today.

The same strategy did not work with the Southern EPs, which by the early 2000s had begun to generate large amounts of cooperation. Refusing to be reclassified as donors when, according to the DAC's own rules, they still had the right to ODA, they rejected scenario $\mathrm{B}$ and joined the Paris Declaration in 2005 as recipients, as in scenario A. The Accra Action Agenda in 2008 took a step forward by recognising that developing countries not only receive aid from the North but also cooperate with one another under SSC rules and principles. This made SSC visible and gave nuance to the narrative of the RCs, but it did not change the status quo: the bipolar North-South divide of scenario A. 
In 2011, the stakes rose in Busan. DAC donors, deeply affected by the financial crisis, were generally in dire straits. Moreover, global challenges, starting with climate change, were mounting. At the same time, Southern EPs, which had fared better during the crisis, had a larger and increasing share of the overall development cooperation portfolio. In this new context, DAC donors were increasingly dissatisfied with the status quo and the rigid North-South divide, in which they bore all the responsibilities. As EPs rejected scenario $\mathrm{B}$ and the traditional donors rejected scenario $\mathrm{A}$, scenario $\mathrm{C}$ won the day in Busan. But it was a Pyrrhic victory that quickly unravelled, opening the way for scenario $\mathrm{D}$, which, as we shall see, has taken root in different ways. The triumph of scenario D over C, which represented a fair formula of burdensharing that could in principle be exported to more consequential regimes, suggests a defeat of international cooperation. In what follows, I will consider why $\mathrm{C}$ failed to gain acceptance and why $\mathrm{D}$, the worst outcome, prevailed in the end.

\subsubsection{The Strategy of Traditional DAC Donors}

With hindsight, we can see that the consolidation of scenario $\mathrm{C}$ faced significant obstacles that went beyond the development cooperation agenda, both from the North and the South. As we have seen, in Busan traditional donors were uneasy with "differentiation" because they saw in it a synonym for "no commitments". But the most powerful donors had a deeper mistrust of scenario $\mathrm{C}$, because even if it meant that the EPs were ready to somehow share the aid burden with them, it would help the latter to consolidate as a distinctive group of like-minded countries (i.e. as "Southern providers"). The rise of the "Global South", dragged by a group of Southern EPs, was beginning to reshape the world economy, fuelling fears that it could also derail the liberal post-war international order and its aid industry. As John Gray has observed, liberalism has always had two faces: a tolerant one ("the search for terms of peace among different ways of life") and an expansionist one ("a prescription of a universal regime") (Gray 2000, p. 8). The liberalism that underpins the post-war order is tilted towards this second, more problematic face, which has been well ingrained in the "crusader mentality" of US foreign policy since the Wilson administration (Anderson 2015; Kissinger 1994).

This latter mindset helps to explain the strong preference of key traditional donors for scenario $\mathrm{B}$ of co-optation and their uneasiness with scenario $\mathrm{C}$ based on differentiation-even in a weak regime such as development effectiveness, for the latter could create a "bad precedent". They feared that the rise of the Global South would reignite the North-South confrontations of the 1970s under new and more menacing circumstances. ${ }^{13}$ To some extent, that danger was real: Though it never came to much, the idea of creating some sort of DAC for Southern providers, which would challenge the monopoly of the DAC on shaping the aid regime, lingered in the air, and there were even some vague attempts to put it into practice (Besharati 2013; Bracho 2015). ${ }^{14}$ 
In sum, key traditional donors were uneasy with the differentiation at the heart of scenario $\mathrm{C}$, not only in its negative interpretation (no commitments), but also in its positive one of different commitments underpinned by a different SSC provider narrative. Finally, a scenario $\mathrm{C}$-in defining different responsibilities for clearly identified groups of providers-incarnated a more structured and harder aid regime than the status quo of scenario $\mathrm{A}$; this at a time when many traditional donors, due to financial stress and/or geopolitical considerations, were striving for a weaker aid regime. Indeed, some traditional donors were keener to move from the status quo of scenario A to the weaker aid regime of scenario D than to the "differentiated commitments" of scenario C.

\subsubsection{The (Diverse) Strategies of the Emerging Powers}

Although key traditional donors were uneasy with scenario C, they had, in principle, accepted it as a gesture to help bring the EPs into the GPEDC in Busan. As Li et al. put it, the concept of differentiated commitments on a voluntary basis was part of the compromise made by the DAC to "buy in more stakeholders, particularly China, India, and others” (Li et al. 2018, p. 149). Nonetheless, as the Korean deal stated, the EPs bore the main responsibility for implementing scenario C through their "sovereign processes", which, as we saw in Sect. 17.1, never really took off. Why did they let this compromise scenario lapse?

To begin, the emerging Southern powers were not clearly united behind scenario C (Bracho 2017). They were all in favour of "differentiation" (i.e. against assuming a donor identity), but they gave the term diverse meanings. Some had the standard negative view of CBDR as an (awkward) concept for no commitments. Others had a more positive one of different commitments. Both views eventually made it into the Busan outcome document, which included an Article (14) backed by Mexico and Brazil stating that the new "providers of South-South cooperation" would eventually participate in the monitoring framework under "differential commitments" (scenario C), and another Article (2), introduced by China and India, that stated that "SouthSouth partners" would take on (Busan) commitments only "on a voluntary basis" (scenario A). But after Busan, the ad hoc alliance behind Article 14 disintegrated, while India and China, now partly joined by Brazil, moved even more forcefully towards scenario A and its traditional SSC narrative with no commitments. Entrenched in scenario A, the main EPs sent the message that they were not willing to participate seriously as providers in the GPEDC. But as they were not willing to do so as recipients either (and nobody expected them to), the message was that they were not willing to participate at all. Accordingly, they left the GPEDC at the eve of the Mexico meeting.

But why did some EPs insist on backing scenario A and others scenario C? At first sight, they all had few incentives for moving away from scenario A, in which-as SSC partners and keeping with their own decades-old SSC narrative- they had a great degree of freedom and no specific responsibilities. This 
narrative had for years allowed them to think of themselves as part of a "homogeneous South", in which they played a leading political and intellectual role, and with which they shared a common colonial or neo-colonial past and had collaborated in the struggles at the UN and other fora (Abdenur 2014; Bracho 2015, pp. 15-16; Esteves and Assunção 2014; Weinlich 2014). Finally, within the framework of the North-South divide, the rapid rise in the amount of SSC that they supplied could be presented as a purely quantitative phenomenon as opposed to a qualitative one, which would have required a shift in their role. In short, why should they take on donor-like responsibilities while they still faced important domestic challenges, their resources were scarce, and the risks of fracturing the political South or losing ODA in practice (whatever the formal rules) were high? These questions haunted - and continue to hauntmiddle-income countries that toy with the idea of adopting a stronger provider identity. ${ }^{15}$

Nevertheless, the EPs also had incentives to move away from scenario A to embrace some version of scenario C (i.e. to shift from a partner to a provider narrative) and gave some signs that they were ready to so. In a recent study on new donors, Gulrajani and Swiss argue that a country is enticed to take on a donor identity "driven by the desire for state legitimacy as an advanced and influential nation" (Gulrajani and Swiss 2017, p. 8). More than prestige is at play. On the eve of the twenty-first century, the Southern EPs had integrated themselves more or less successfully into the whirlpool of globalisation and were eager to match their new economic status with a more relevant political one on the international stage. They signalled, in various ways, that they were ready to take on more responsibilities at the regional level, and some even at the global level—and development cooperation is indeed an ideal tool of soft power to do so (Nye 2011).

Moreover, the major EPs were not only offering much more cooperation, but also behaving politically as providers. Both China and India created institutional frameworks in which their leaders periodically met with their African counterparts to announce large "cooperation" programmes. Brazil and Turkey also took a visible political stand as providers. Finally, these powers were also giving signs that they no longer considered the traditional SSC framework (in terms of narrative and institutions) to be adequate for representing their new roles and the new reality, as when India launched the Delhi process for renovating SSC (Bracho 2015; Fues 2018), and China issued white papers on aid that were not clearly rooted in a traditional SSC narrative (Information Office of the State Council of the People's Republic of China 2011, 2014).

In sum, it is fair to say that the EPs had incentives to entrench themselves in scenario A but also incentives to move towards scenario C. The former option made headway in India, which was still a low-middle-income country marred by poverty. In contrast, China had fewer incentives to opt for scenario A in principle, but these were boosted by deep concerns with the DAC and the effectiveness agenda- a mix that gave way to a defensive strategy. Li et al. (2018) identify four such concerns, which they apply to the "rising powers", 
but which were especially relevant to China. These are: political legitimacy, attribution of responsibilities, definition of the agenda, and trust (Li et al. 2018, pp. 151-152).

The first concern-political legitimacy — is based on the fact that, despite the formal participation of the UNDP in its Secretariat, the GPEDC is not a universal UN body but rather one that is still presumably driven by the OECD-DAC. This concern was expressed from the outset, but had it been paramount, the EPs (which collaborate with the OECD on many other topics) would never have participated in the effectiveness agenda in the first place.

The second concern is in fact about "burden-sharing", which I have put at the centre of the whole story and which the EPs perceived in a negative way. As Professor Li argues, China perceived the GPEDC as a ploy of the DAC donors to share their "heavy burden accumulated over the decades" (Li 2017, p. 7), and thus dilute their own contributions to development-considering the aid burden as a zero-sum game (Weinlich 2014). In other words, the EPs did not perceive "burden-sharing" as an honest attempt to bring them into the agenda as providers; even when they were joining with "differential commitments", they remained suspicious of the project. They welcomed the inclusion of this concept as a "big compromise" (Li 2017, p. 7; Li et al. 2018, p. 149), but they did not take it seriously.

Li et al. (2018) identify the "definition of the agenda" as the EPs' third concern. I see this in a broader sense as a concern that the GPEDC would not be a venue where "differences" would be respected but rather a forum to pressure the EPs to accept the Western aid paradigm embedded in the postwar liberal regime. As we have seen, this was a well-grounded concern: The post-war liberal regime is indeed driven by a "crusader mentality" (Lind and Wohlford 2019).

The fourth and final concern was trust-a crucial ingredient for international endeavours to succeed (Messner et al. 2013). To a certain extent, most of the other concerns boil down to a lack of trust. The Busan compromise of scenario C portrayed the GPEDC as a neutral venue underpinned by the participation of the UNDP, which would respect differences among narratives, practices, and levels and types of commitments. The EPs were happy with this message, but some doubted that the DAC donors really meant it. Lacking trust, they perceived the GPEDC and its talk about transcending the NorthSouth divide and transitioning from "aid to development effectiveness" as a smokescreen to coerce them into an unfair "burden-sharing" exercise and the liberal Western aid regime. As they lacked the intellectual and institutional resources of the North to be able to counter this with a modern Southern narrative of their own (a factor explored in $\mathrm{Li} 2017$; $\mathrm{Li}$ et al. 2018), they preferred to adopt a defensive strategy and to stick to what they knew: the traditional SSC discourse. This allowed them to stay in the comfort zone of "no responsibilities" and the long-established discourse of the homogeneous South developed by the UN. They thus defended the status quo of scenario A rather than venture into the presumed "trap" of a new scenario C-though, 
in fact, as we have argued, the traditional donors were not so sure about the virtues of scenario $\mathrm{C}$ themselves.

Following this logic, the EPs that backed scenario $\mathrm{C}$ were those that did not share as much the concerns that haunted China and others. Take the case of Mexico (Villanueva Ulgard and López Chacón 2017; Bracho 2017). It was eager to participate in the effectiveness agenda, but like all other Southern EPs, it refused to be reclassified as a donor (i.e. it rejected scenario B) and considered itself part of the SSC community. Yet, in contrast with most other Southern countries and as a member of the OECD, an observer at the DAC, and a country that no longer belonged to the G77, Mexico had fewer political constraints and much less of a trust deficit. Therefore, it actively advocated for scenario C. Moreover, as it shared the values and policies of the post-war liberal order, the "costs" that Mexico might have had to pay by eventually joining the GPEDC and its monitoring framework as a provider were much lower. But being a modest provider and one too close to the North to have the required legitimacy, Mexico was not in a position to lead the South. ${ }^{16}$ Without the support of the big Southern players, scenario C was bound to collapse-and eventually did.

\subsubsection{The Strategy of Recipient Countries}

I will now explore the position of RCs in the "burden-sharing battle" among traditional donors and EPs-acknowledging their limited clout due to the power asymmetries among these three actors. The model reckons that RCs are better off under scenario B (10 units) and thus predicts they would join the traditional donors in pressuring the EPs to adopt full donor identity and responsibilities. The model also suggests that recipients would prefer scenario $\mathrm{C}$ to the status quo of scenario $\mathrm{A}$ and would receive ever-diminishing benefits from scenario D. Nonetheless, the facts only partially confirm these predictions. Traditional donors have expected RCs to join them in "disciplining" the EPs. To some extent, the latter have done so, as when they have publicly asked the EPs to be more transparent and/or to untie more of their aid, or when they have reported the "donor activities" of those powers, as they did when they precipitated the collapse of the Korean deal.

But RCs have not advocated in a systematic way for scenario B-not even in the negotiations of the Busan outcome document and the Mexican communiqué, when they mostly stayed away from the negotiations between traditional donors and EPs. They had reasons to take this hands-off approach.

First, many RC's preferred to see traditional donors and EPs competing with each other rather than coalescing into a common donor group. This outcome was compatible with scenarios A, C, and D, but not with scenario B. This preference for competition can be explained in different ways: (i) one possibility is that RCs do not consider the Western aid regime to be wellaligned with their own interests ${ }^{17}$; (ii) another is that they gauge that Western donors and EPs have distinctive comparative advantages, and thus wanted to 
keep them separate to benefit fully from both (Bracho and Grimm 2016); and (iii) finally, it is possible that-independent of their assessment of Western donors and EPs as providers of aid-they prefer to keep them separate to increase their own negotiating power (Greenhil et al. 2016), much as they often did with Western and Soviet aid during the Cold War.

Second, RCs rejected scenario B out of their allegiance to the common house of the South. Just as the EPs hesitated to portray themselves as Southern providers, let alone donors, RCs-for deeply rooted historical reasons-are reluctant to demand that they do so. For both actors, path dependence reinforced the status quo of scenario A (North 2005).

The first argument for "competition" suggests why recipients would not be as keen for scenario B as the model suggests. But it does not rule out scenario $\mathrm{C}$, in which the EPs retain their differences and comparative advantages, and thus continue to compete as providers while assuming well-defined responsibilities. Indeed, scenario C would fit into a framework of healthy, structured competition that avoids the race-to-the-bottom type exemplified by scenario $\mathrm{D}$.

In contrast, the second argument-the allegiance to a "common Southern identity"-rules out not only scenario B but also C, and it leaves scenario A as the only strategy to follow, which is indeed what recipient continue to do, especially at UN fora. But if, as the game suggests, scenario A is suboptimal in terms of benefits, RCs, by keeping to a narrative of a homogeneous South, do not seem to be following the strategy that best represents their long-term interests and the common good. Moreover, by entrenching themselves in scenario A, both RCs and EPs have indirectly contributed to pushing the development cooperation agenda towards the overall weaker aid regime of scenario D.

\subsubsection{Sliding into Scenario D of a Weak Aid System}

Since the collapse of the GPEDC as a global forum, the weaker aid regime of scenario $\mathrm{D}$ has been gaining ground through three mutually reinforcing trends or processes: (i) the so-called Southernisation of the traditional donors' narrative and practices; (ii) the decline of the EP's agenda and the failure of the EP's to assume a coherent Southern provider identity; and (iii) the universalisation of the development cooperation agenda and the erosion of the North-South divide. I will consider each of these in turn.

As the literature has rightly observed, there has been a movement towards convergence between North-South cooperation and SSC through the socalled Southernisation of the Northern narrative, practices, and commitments (Bracho 2015; Fues 2015; Klingebiel and Esteves 2021; Mawdsley 2018). Instead of the DAC socialising the EPs (as in scenario B), the opposite has been taking place: Traditional donors have been co-opting the Southern narrative. DAC members do not consider themselves "donors" anymore, but rather "providers"; they now classify their assistance as "cooperation" rather 
than "aid"; they portray their aid relations as "horizontal partnerships among equals" rather than as "vertical relations among principals and clients"-as was the case, and often explicitly so, in the past; they now present their aid as stemming from "voluntary commitments" rather than from "historical responsibilities"; finally, they consider their assistance to be motivated by "mutual benefit" rather than "altruism".

To some extent, traditional donors have been co-opting Southern language to keep up with the more politically inclusive times, and this has had its positive effects. Thus, for example, partnership has not been an empty word, and developing countries now have a greater say in the aid industry than they did in the early days of the agenda. Moreover, by closing the gap between the narratives of the South and the North, Southernisation is contributing to a convergence that could help to re-create a global aid regime in the future (Janus and Tang 2021).

But more worryingly, Southernisation has also been about moving to a new, looser aid system, as with the one the Southern EPs enjoy in practice: a system with both lower and/or fewer commitments and weaker and more flexible rules. Since Gleneagles in 2005 and Accra in 2008, DAC donors have not made significant new collective commitments and have watered down earlier ones, including the 0.7 per cent of gross domestic product, the mother of all donor commitments. ${ }^{18}$

DAC donors have also loosened their own rules. For example, they have been tearing down the once stringent barrier between ODA and profit-making commercial flows - the crucial distinction on which their whole narrative and paradigm were built. ${ }^{19}$ Here they are again following China, which often provides aid as part of "packages", mixing it with trade and investment and tying it to the use of its own companies' products and services (Bracho 2018b; Brautigam 2009, 2011).

Finally, and somehow paradoxically, by allowing countries to put their national interests above—or at an equal level with-development, Southernisation has been helping donor agencies to cope with the challenges of rising populism at home. Thus, it also has its silver lining (Gulrajani 2018; Kharas and Rogerson 2017).

Since the decline of the GPEDC as a global forum, developments in the South have also contributed to the move towards scenario D of a weaker and uncoordinated aid regime. Some Southern EPs have in practice reinforced their profile as providers. China, by far the most important, has continued to increase the volume and scope of the cooperation it provides, particularly through the Belt and Road Initiative. By launching a cooperation agency and spearheading the creation of new multilateral development banks, China has also engaged in institution-building. In a sense, it is creating the scaffolding for an alternative aid regime in competition with the West, reviving thus the possibility of a Cold War-like scenario in which two groups of donors compete for the allegiance of RCs (Bracho 2018b). Other Southern EPs, such as India and 
Turkey, have also maintained or increased important volumes of development cooperation (DEVEX 2019).

But neither they nor China have assumed a coherent Southern provider identity and narrative. Indeed, their discourse often shifts radically according to the audience and/or the venue. Moreover, now that the economic boom of the early years of the century is over, the Southern provider agenda has actually moved backwards in some countries and regions, particularly in Latin America. The two main providers of the region have fallen into dire straits: The Venezuelan economy has collapsed entirely, and Brazil, now in a deep recession, has turned its back on Lula da Silva's activist policies towards the South. At the same time, Chile's and Uruguay's badly managed graduations from ODA have helped to push them and other upper-middle-income countries, including Mexico, into recipient mode. ${ }^{20}$ Not only has the agenda of the Southern providers not advanced in Latin America, but it has also given way to a new narrative of development in transition, which is geared to justify why the high-middle-income countries of the region are still in need of development cooperation (Barcena et al. 2017; OECD et al. 2019).

All these trends came together in March 2019 at the recent Second HighLevel UN Conference on SSC: the Buenos Aires Plan of Action plus 40 $(\mathrm{BAPA}+40)$. There were some expectations that $\mathrm{BAPA}+40$ would really take stock of the massive changes that had occurred in the agenda since the first conference 40 years ago (Bracho 2018a; Klingebiel and Esteves 2018). But although the outcome document recognised the new role of triangular cooperation (Article 28) and advances in the institutionalisation of SSC (Article 26), it failed to acknowledge what arguably is the main novelty in the agenda: the emergence of the Southern provider. This concept appeared once in the original draft in a somewhat weak fashion but soon disappeared altogether. BAPA +40 failed to recognise differentiation among the countries of the South and did not integrate CBDR in its framework, as some important players (Faurie 2018) and observers expected (Klingebiel and Esteves 2018). In balance, BAPA +40 opted for the status quo narrative of scenario A, in which the Southern EPs assume no special responsibilities or commitments towards their poorer or less capable Southern brothers, and in so doing reinforced the downward slide of the whole agenda towards scenario D.

The third factor pushing towards a weaker aid system is universalisation. Unlike the MDGs, the Sustainable Development Goal (SDG) agenda is for all countries: poor and rich. This shift is the result of a powerful political narrative that regards all countries as being in the same boat, and which recognises that rich countries also face development challenges, and also that the South might be able to assist with the problems of the North (Longhurst 2017). This move towards universality received universal praise. Moreover, it was primarily the South-tired of the patronising North-that lobbied for universalisation. But now that the euphoria which accompanied its adoption in 2015 is dissipating, the SDG agenda is beginning to show a number of shortcomings. By deconstructing the North-South divide and treating all countries as 
"developing", the movement towards universalisation has lost focus on the real developing countries and has dissipated responsibilities, reinforcing the narrative and practices of the weaker aid system of scenario D (Bracho 2015; Esteves 2017).

\subsection{CONCLUSIONS}

This chapter has shown how the traditional and the Southern EPs briefly agreed on a rough framework on how to "share the burden" in the development effectiveness agenda in Busan. It has also put forward an explanation as to why and how the Busan promise of bringing together all major development cooperation providers under one tent rapidly collapsed. Finally, the essay describes how the collapse of this project could be considered part of the broader erosion of the traditional aid system and the decline of the liberal post-war order. Other authors evaluate these trends more positively. They consider the erosion of the aid system to be an adaptation to the challenges of new times: for example, the need to mobilise private capital or to counteract populism (Kharas and Rogerson 2017). Or they emphasise the benefits produced by competition from the Southern providers, who bring new resources, ideas, and practices (Greenhil et al. 2016). I do not deny that the erosion of the post-war aid system has to a certain extent been caused by good intentions, nor that it has led to some good outcomes. My main concern is that it is not giving way to an alternative global development cooperation regime.

In his piece in this volume, André de Mello e Souza makes a strong case for such a regime on the grounds of overall efficiency, including the need to tackle inconsistencies among different SDGs. Building on his analysis, I would argue that it is becoming a matter of survival. It is true that development cooperation-with or without a regime-contributed little towards achieving the MDGs, as most poverty reduction was achieved by China's ("dirty") economic growth. But development cooperation under a burden-sharing framework that clarifies "who should do what and how" will be crucial to tackling climate change and inequality, which are the main global challenges that are putting our planet and our civilisation at risk. These challenges cannot be confronted effectively without real collective action. Moreover, as the interdependence and "public bads" have multiplied, development cooperation has become part and parcel of a much broader international cooperation agenda. The principle of "self-differentiation" agreed in the Paris' climate negotiations, in which each country in "a responsible way" defines its own responsibilities, is clearly not enough (Liti Mbeva and Pauw 2016).

It is in this context that, even if development cooperation effectiveness plays a relatively minor role in this broad agenda, the story and analysis of the 
rise and fall of the Busan promise can provide useful lessons on the types of concerns and arguments that are keeping the International Community from really working together. Only thus can development cooperation realise its potential and contribute positively towards achieving the SDGs.

\section{Notes}

1. There is no consensual typology and nomenclature for the "actors" that participate in the development cooperation agenda. I herewith use the following ad hoc definitions: "Traditional DAC donors" stands for the members of the DAC of the OECD. "Recipient partner countries" (RC's) are countries included in the DAC list of RCs entitled to receive official development assistance (ODA). "Non-DAC" donors are countries that are not members of the DAC or included in the DAC list and offer meaningful volumes of development cooperation. "Providers of South-South cooperation" or "Southern providers" are countries that are still in the DAC list and, at the same time, offer meaningful volumes of development cooperation.

2. Following Stephen Krasner, "Regimes can be defined as a set of implicit or explicit, principles, norms, rules and decision making procedures around which actors' expectations converge in a given area of international relations" (Krasner 1983, p. 2).

3. In contrast to China and India, Brazil did attend the meeting, but publicly stated that it was not a member of the GPEDC.

4. For a comprehensive history of the Aid Effectiveness agenda, see Abdel-Malek (2015) for a firsthand account of the Busan meeting, see Atwood (2012) for a recount on Busan focussing on the role of the Southern Providers, see Bracho (2017), Eyben and Savage (2013), Kharas (2011), Mawdsley et al. (2014), as well as Villanueva Ulgard and López Chacón (2017).

5. This is no longer true for Chile and Uruguay. We will come back later to the issue of their recent graduation.

6. The conspicuous exceptions are India and Indonesia, which are still classified as low-middle-income countries.

7. The full text of the Korean deal and its rationale is reproduced as Annex 2 in Bracho (2017).

8. Among these processes and initiatives, three stand out: the Delhi process, the UNDESA initiative of a Core Group of Southern Partners, and the creation of a Network of Southern Think-Tanks (NEST) largely focussing in SSC (Besharati 2013; Bracho 2015; Fues 2018).

9. That is, the costs that donors incur with commitments such as: (i) compliance with recipients' priorities (Busan's 1st), or the cost to process and publish their information in order to be more transparent (Busan's 4th), or make multiannual plans and be more predictable (Busan's 5th).

10. See the chapter in this volume by Nilima and Rachel, where they argue that the national interest and the common good do not necessarily conflict.

11. The exercise is inspired in basic game theory. In fact, as RCs have less power, and thus scarce agency, it could be to some extent re-casted as a prisoner's dilemma game with two players (DD and EP) and an equilibrium solution reached by cooperation among them. I am grateful to De Mello e Souza for pointing this out. 
12. The differential commitments or responsibilities for Southern providers could be of the same type but implying a lower burden than those that apply for traditional donors-say provide 0.1 per cent instead of 0.7 per cent of GDP as official development aid, as Jeffrey Sachs has suggested (Sachs and SchmidtTraub 2014). But they could also be fewer-say, exempt Southern providers from the commitment to untie their aid.

13. Some authors have seen the rise of the EPs in the development cooperation agenda as heralding the reconstitution of the political South striving-like in the 1970s-for an alternative world order. See Bockman (2015), DomínguezMartín (2016, 2017), and Gosovic (2016).

14. Be it at the Heiligendamm process, at the G20, or at the GPEDC, Northern powers tried to discourage any prospect of the EPs forming a coherent group (Aranda Bezaury and Díaz Ceballos Parada 2010; Bracho 2015).

15. According to Li et al., middle-income countries will only (re)join the GPEDC as providers, when they "feel the security of showing international dominance as donors of development aid without fearing further decreases of ODA to their countries" (Li et al. 2018, p. 151).

16. Nonetheless, almost single-handedly, Mexico has continued to push forward the agenda of "adapting" the GPEDC principles and monitoring framework to SSC (Agencia Mexicana de Cooperación Internacional para el Desarrollo 2019).

17. Contrary to what the model assumes, as we warned, the cost of aid for donors will not automatically translate into benefits for recipients. One can argue that this happened during the 1980s and 1990s, when the aid regime was subordinated to push forward the Washington Consensus aligned to the interests of the North, but not generally speaking to those of the South (Fukuda-Parr 2014; Glennie 2008).

18. Since the Finance for Development summit in Addis Ababa (2015), every major international document stipulates that some DAC donors commit to the 0.7 target while others do not-a clear message that it is about a "voluntary commitment", not a "responsibility". Some donors have even turned away from previous commitments on ODA quantities that they had taken before, for example Australia (Organisation for Economic Co-operation and Development [OECD] 2018, p. 23).

19. Previous DAC chairs have rightly raised their concerns about the perils of this trend (Atwood et al. 2018; Manning 2013).

20. Chile and Uruguay graduated from the DAC list of ODA recipient countries in 2018. But rather than rejoicing, they complained, arguing that they still faced many development challenges and, rightly so, that income per capita was not (at least not anymore) a good indicator to gauge development.

\section{REFERENCES}

Abdel-Malek, T. (2015). The Global Partnership for Effective Development Cooperation: Origins, actions and future prospects (Studies 88). Bonn: German Development Institute/Deutsches Institut für Entwicklungspolitik (DIE).

Abdenur, A. E. (2014). Emerging powers as normative agents: Brazil and China within the UN development system. Third World Quarterly, 35(10), 1876-1893. 
Agencia Mexicana de Cooperación Internacional para el Desarrollo. (2019). Monitoring exercise in South-South cooperation effectiveness: Final report. https://www. gob.mx/cms/uploads/attachment/file/447837/EJERCICIO_DE_MONITO REO_2019-eng.pdf.

Anderson, P. (2015). American foreign policy and its thinkers. London: Verso.

Aranda Bezaury, M., \& Díaz Ceballos Parada, B. (2010). México y los cambios en la arquitectura económica internacional. In B. Torres \& G. Vega (Eds.), Los grandes problemas de México: Relaciones internacionales (Vol. 7, pp. 651-673). Mexico: El Colegio de México.

Atwood, B. (2012). Creating a Global Partnership for Effective Development Cooperation. https://www.cgdev.org/sites/default/files/1426543_file_Atwood_Busan_ FINAL_0.pdf.

Atwood, B. J., Manning, R., \& Riegler, H. (2018, December 21). Don't undermine the basic architecture of $O E C D / D A C$ statistics: A letter of warning. https:// www.brookings.edu/blog/future-development/2018/12/21/dont-underminethe-basic-architecture-of-oecd-dac-statistics-a-letter-of-warning/.

Barcena, A., Manservisi, S., \& Pezzini, M. (2017, July 3). Opinion: It's time to change the way we think about development policy. DEVEX. https://www.devex. $\mathrm{com} /$ news/opinion-it-s-time-to-change-the-way-we-think-about-development-pol icy-90605.

Besharati, N. A. (2013). Common goals and differential commitments: The role of emerging economies in global development (DIE Discussion Paper 26/2013). Bonn: German Development Institute/Deutsches Institut für Entwicklungspolitik (DIE).

Bockman, J. (2015). Socialist globalization against capitalist neocolonialism: The economic ideas behind the new international economic order. Humanity: An International Journal of Human Rights, Humanitarianism, and Development, 6(1), 109-125.

Bracho, G. (2015). In search of a narrative for Southern providers: The challenge of the emerging economies to the development cooperation agenda (DIE Discussion Paper 1/2015). Bonn: German Development Institute/Deutsches Institut für Entwicklungspolitik (DIE).

Bracho, G. (2017). The troubled relationship of the emerging powers and the effective development cooperation agenda (DIE Discussion Paper 25/2017). Bonn: German Development Institute/Deutsches Institut für Entwicklungspolitik (DIE).

Bracho, G. (2018a). Towards a common definition of South-South cooperation: Bringing together the spirit of Bandung and the spirit of Buenos Aires. Development Cooperation Review, 1(6), 9-13.

Bracho, G. (2018b). El CAD y China: origen y fin de la ayuda al desarrollo. Revista CIDOB d'Afers Internacionals, 120, 215-239.

Bracho, G., \& Grimm, S. (2016). South-South cooperation and fragmentation: A nonissue. In S. Klingebiel, T. C. Mahn, \& M. Negre (Eds.), The fragmentation of aid: Concepts, measurements and implications for development cooperation (pp. 121-134). London: Palgrave Macmillan.

Brautigam, D. (2009). The dragon's gift: The real story of China in Africa. Oxford: Oxford University Press.

Brautigam, D. (2011). Aid "with Chinese characteristics": Chinese foreign aid and development finance meet the OECD-DAC aid regime. Journal of International Development, 23(5), 752-764. 
Constantine, J., Shankland, A., \& Gu, J. (2015). Engaging the rising powers in the Global Partnership for Effective Development Cooperation (Working Paper). Sussex: Institute of Development Studies.

De Mello e Souza, A. (2021). Building a global development cooperation regime: Necessary but failed efforts. In: Palgrave this volume.

DEVEX (2019). Emerging donors 2.0. https://pages.devex.com/rs/685-KBL-765/ images/Devex-Emerging-Donors-Report.pdf.

Domínguez-Martín, R. (2016). Cooperación financiera para el desarrollo, ADN de la cooperación Sur-Sur. Iberoamerican Journal of Development Studies, 5(1), 62-86.

Domínguez-Martín, R. (2017). En los pliegues de la historia: Cooperación Sur-Sur y procesos de integración en América Latina y el Caribe. Estudios Internacionais Belo Horizonte, 4(2), 57-78.

Esteves, P. (2017). Agora somos todos países em desenvolvimento? A Cooperacao Sul-Sul os ODS. Pontes, 13(2). https://www.ictsd.org/bridges-news/pontes/ news/agora-somos-todos-pa\%C3\%ADses-em-desenvolvimento-a-coopera\%C3\%A7\% C3\%A3o-sul-sul-e-os-ods.

Esteves, P., \& Assunção, M. (2014). South-South cooperation and the international development field: Between the OECD and the UN. Third World Quarterly, 35(10), 1775-1790.

Eyben, R., \& Savage, L. (2013). Emerging and submerging powers: Imagined geographies in the new development partnership at the Busan Fourth High Level Forum. Journal of Development Studies, 49(4), 457-469.

Faurie, J. (2018). Next year BAPA +40 is a unique opportunity to forge a new global consensus for international development co-operation. In OECD, development co-operation report 2018: Joining forces to leave no one behind (p. 268). Paris: Organisation for Economic Co-operation and Development.

Fues, T. (2015). Converging practices and institutional diversity: How Southern providers and traditional donors are transforming the international system of development cooperation. In E. Sidiropoulos, J. A. Pérez Pineda, S. Chaturverdi, \& T. Fues (Eds.), Institutional architecture and development (pp. 24-42). Johannesburg: South African Institute of International Affairs.

Fues, T. (2016, April 11). South-South cooperation: Global force, uncertain identity (The Current Column). Bonn: German Development Institute/Deutsches Institut für Entwicklungspolitik (DIE).

Fues, T. (2018). Convergence on South-South cooperation: The Delhi process after five years. Development Cooperation Review, 1(6), 3-8.

Fukuda-Parr, S. (2014). Should global goal-setting continue, and how, in the post2015 era? In J. Alonso, A. Cornia, \& R. Vos (Eds.), Alternative development strategies in the post-2015 era (pp. 35-67). London: Bloomsbury Press.

Glennie, J. (2008). The trouble with aid: Why less could mean more for Africa. London: Zed Books.

Gosovic, B. (2016). The resurgence of South-South cooperation. Third World Quarterly, 37(4), 733-743.

Gray, J. (2000). Two faces of liberalism. New York, NY: The New Press.

Greenhil, R., Prizzon, A., \& Rogerson, A. (2016). The age of choice: Developing countries in the new aid landscape. In S. Klingebiel, T. Mahn, \& M. Negre (Eds.), The fragmentation of aid: Concepts, measurements and implications for development cooperation (pp. 137-152). London: Palgrave Macmillan.

Gulrajani, N. (2018, January). Merging development agencies: Making the right choice (ODI Briefing Note). London: Overseas Development Institute. 
Gulrajani, N., \& Swiss, L. (2017, March). Why do countries become donors? London: Overseas Development Institute.

Information Office of the State Council of the People's Republic of China. (2011). China's foreign aid. http://english.gov.cn/archive/white_paper/2014/09/09/con tent_281474986284620.htm.

Information Office of the State Council of the People's Republic of China. (2014). China's foreign aid. http://english.gov.cn/archive/white_paper/2014/08/23/con tent_281474982986592.htm.

Janus, H., \& Tang, L. (2021). Conceptualising ideational convergence of China and OECD donors: Coalition magnets in development cooperation. In: Palgrave this volume.

Kaul, I. (2000, June). What is a public good? Le Monde Diplomatique (English edition). https://mondediplo.com/2000/06/15publicgood.

Kharas, H. (2011). Coming together: How a new partnership on development cooperation was forged at the Busan High Level Forum on Aid Effectiveness. http://www. realinstitutoelcano.org/wps/portal/rielcano_en/contenido?WCM_GLOBAL_CON TEXT =/elcano/elcano_in/zonas_in/ARI\%20164-2011.

Kharas, H., \& Rogerson, A. (2017). Global development trends and challenges: Horizon 2025 revisited. https://www.odi.org/publications/10940-global-development-tre nds-and-challenges-horizon-2025-revisited.

Kim, E. M., \& Lee, J. E. (2013). Busan and beyond: South Korea and the transition from aid effectiveness to development effectiveness. Journal of International Development, 25, 787-801.

Kindornay, S., \& Samy, Y. (2012). Establishing a legitimate development co-operation architecture in the Post-Busan era. Ottawa: The North-South Institute.

Kissinger, H. (1994). Diplomacy. New York, NY: Simon and Schuster.

Klingebiel, S., \& Esteves, P. (2018, September 12). On the way to the 2nd UN conference on South-South cooperation (The Current Column). Bonn: German Development Institute/Deutsches Institut für Entwicklungspolitik (DIE).

Klingebiel, S., \& Esteves, P. (2021). Diffusion, fusion, and confusion: Development cooperation in a multiplex world order. In: Palgrave this volume.

Krasner, S. D. (1983). Structural causes and regime consequences: Regimes as intervening variables. In S. D. Krasner (Ed.), International regimes (pp. 1-21). Ithaca, NY: Cornell University Press.

Li, X. (2017). Should China join the GPEDC? The prospects for China and the Partnership for Effective Development Cooperation (DIE Discussion Paper 17/2017). Bonn: German Development Institute/Deutsches Institut für Entwicklungspolitik (DIE).

Li, X., Gu, J., Leistner, S., \& Cabral, L. (2018). Perspectives on the Global Partnership for Effective Development Cooperation. IDS Bulletin, 49(3), 145-165.

Lightfoot, S., \& Kim, S. (2017). The EU and the negotiation of global development norms: The case of aid effectiveness. European Foreign Affairs Review, 22(2), 159176.

Lind, J., \& Wohlford, W. C. (2019). The future of the liberal order is conservative. Foreign Affairs, 98(2), 70-82.

Liti Mbeva, K., \& Pauw, P. (2016). Self-differentiation of countries' responsibilities (DIE Discussion Paper 4/2016). Bonn: German Development Institute/Deutsches Institut für Entwicklungspolitik (DIE).

Longhurst, R. (Ed.) (2017). Has universal development come of age? IDS Bulletin, $48(1 \mathrm{~A})$. 
Manning, R. (2013, April 9). OECD is ignoring its definition of overseas aid. Financial Times. https://www.ft.com/content/b3d73884-a056-11e2-88b600144 feabdc0.

Mawdsley, E. (2018). The "Southernization" of development. Asia Pacific View Point, $59(3), 173-185$.

Mawdsley, E., Savage, L., \& Kim, S.-M. (2014). A “post-aid world”: Paradigm shift in foreign aid and development cooperation at the 2011 Busan High Level Forum. The Geographical Journal, 180(1), 27-38.

Messner, D., Guarín, A., \& Haun, D. (2013). The behavioural dimensions of international cooperation. Duisburg: Käte Hamburger Kolleg/Centre for Global Cooperation Research.

North, D. C. (2005). Understanding the process of economic change. Princeton, NJ: Princeton University Press. (Original work published 1990.)

Nye, J. S. (2011). The future of power. New York, NY: Public Affairs.

OECD (Organisation for Economic Co-operation and Development). (2018). OECD development co-operation peer reviews: Australia 2018. https://doi.org/10.1787/ 9789264293366-en.

OECD, CAF, \& UN ECLAC. (2019). Latin American economic outlook: Development in transition. https://doi.org/10.1787/g2g9ffl8-en.

Olson, M. (1965). The logic of collective action: Public goods and the theory of groups. Cambridge, MA: Harvard University Press.

Quadir, F. (2013). Rising donors and the new narrative of "South-South" cooperation: What prospects for changing the landscape of development assistance programmes? Third World Quarterly, 34(2), 321-328.

Sachs, J. D., \& Schmidt-Traub, G. (2014). Financing sustainable development: Implementing the SDGs. Sustainable Development Solutions Network. New York, NY: United Nations.

Villanueva Ulgard, R., \& López Chacón, L. (2017). In search of making a difference: Mexico in the OECD international development co-operation architecture. Development Policy Review, 35(2), 287-302.

Weinlich, S. (2014). Emerging powers at the UN: Ducking for cover? Third World Quarterly, 35(10), 1829-1844.

WP-EFF (Working Party on Aid Effectiveness). (2011). Compendium of written proposals received based on the third draft outcome document for HLF-4. Paris: Organisation for Economic Co-operation and Development.

WP-EFF. (2012). Note prepared by Korea on global monitoring: Participation of South-South cooperation providers in the Busan Global Monitoring framework (DCD$D A C-E F F-M$ [2012]3). Annex 2, pp. 20-21. Paris: Organisation for Economic Co-operation and Development. 
Open Access This chapter is licensed under the terms of the Creative Commons Attribution 4.0 International License (http://creativecommons.org/licenses/by/4.0/), which permits use, sharing, adaptation, distribution and reproduction in any medium or format, as long as you give appropriate credit to the original author(s) and the source, provide a link to the Creative Commons license and indicate if changes were made.

The images or other third party material in this chapter are included in the chapter's Creative Commons license, unless indicated otherwise in a credit line to the material. If material is not included in the chapter's Creative Commons license and your intended use is not permitted by statutory regulation or exceeds the permitted use, you will need to obtain permission directly from the copyright holder. 